\title{
2010s-31
}

\section{Analyzing Entry Strategies in the Canadian Wireless Industry: The Case of the Discount Market}

\author{
Sandy William Mokbel
}

\section{Série Scientifique \\ Scientific Series}

\author{
Montréal \\ Août 2010 \\ (Les données factuelles contenues dans ce rapport sont celles qui \\ étaient disponibles en décembre 2009)
}

(C) 2010 Sandy William Mokbel. Tous droits réservés. All rights reserved. Reproduction partielle permise avec

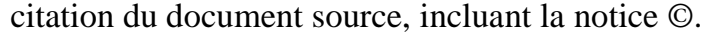

Short sections may be quoted without explicit permission, if full credit, including $@$ notice, is given to the source.
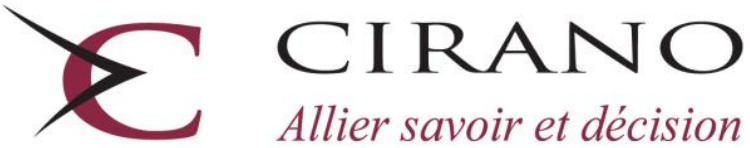

Allier savoir et décision

Centre interuniversitaire de recherche en analyse des organisations 


\section{CIRANO}

Le CIRANO est un organisme sans but lucratif constitué en vertu de la Loi des compagnies du Québec. Le financement de son infrastructure et de ses activités de recherche provient des cotisations de ses organisations-membres, d'une subvention d'infrastructure du Ministère du Développement économique et régional et de la Recherche, de même que des subventions et mandats obtenus par ses équipes de recherche.

CIRANO is a private non-profit organization incorporated under the Québec Companies Act. Its infrastructure and research activities are funded through fees paid by member organizations, an infrastructure grant from the Ministère du Développement économique et régional et de la Recherche, and grants and research mandates obtained by its research teams.

\section{Les partenaires du CIRANO}

Partenaire majeur

Ministère du Développement économique, de l'Innovation et de l'Exportation

\section{Partenaires corporatifs}

Banque de développement du Canada

Banque du Canada

Banque Laurentienne du Canada

Banque Nationale du Canada

Banque Royale du Canada

Banque Scotia

Bell Canada

BMO Groupe financier

Caisse de dépôt et placement du Québec

Fédération des caisses Desjardins du Québec

Gaz Métro

Hydro-Québec

Industrie Canada

Investissements PSP

Ministère des Finances du Québec

Power Corporation du Canada

Raymond Chabot Grant Thornton

Rio Tinto

State Street Global Advisors

Transat A.T.

Ville de Montréal

\section{Partenaires universitaires}

École Polytechnique de Montréal

HEC Montréal

McGill University

Université Concordia

Université de Montréal

Université de Sherbrooke

Université du Québec

Université du Québec à Montréal

Université Laval

Le CIRANO collabore avec de nombreux centres et chaires de recherche universitaires dont on peut consulter la liste sur son site web.

Les cahiers de la série scientifique (CS) visent à rendre accessibles des résultats de recherche effectuée au CIRANO afin de susciter échanges et commentaires. Ces cahiers sont écrits dans le style des publications scientifiques. Les idées et les opinions émises sont sous l'unique responsabilité des auteurs et ne représentent pas nécessairement les positions du CIRANO ou de ses partenaires.

This paper presents research carried out at CIRANO and aims at encouraging discussion and comment. The observations and viewpoints expressed are the sole responsibility of the authors. They do not necessarily represent positions of CIRANO or its partners. 


\title{
Analyzing Entry Strategies in the Canadian Wireless Industry: The Case of the Discount Market
}

\author{
Sandy William Mokbel
}

\begin{abstract}
Résumé / Abstract
Cette étude examine les stratégies d'entrée sur le marché canadien des télécommunications sans-fil à escompte. L'analyse porte principalement sur les choix stratégiques des entreprises établies qui font face à des menaces d'entrée séquentielles sur le marché. Le modèle, essentiellement basé sur la taxonomie des stratégies de gestion de Fudenberg et Tirole, est étudié dans un contexte de firmes ayant des contacts sur plusieurs marchés et en supposant que la dissuasion à l'entrée pourrait avoir les mêmes caractéristiques qu'un bien public. L'analyse se base sur deux jeux à deux phases interconnectés. Ce modèle supposerait alors que Fido, Solo et Virgin auraient adopté la stratégie d'un Gentil Chiot en préparation à l'entrée de Koodo, et se seraient ensuite alignés avec leur nouveau concurrent en adoptant ce qui semblerait être une attitude de Chien Méchant lorsque soumis à des menaces d'une nouvelle vague d'entrées.
\end{abstract}

Mots clés : stratégie de marché, théorie des jeux, télécommunications, organisation industrielle

This study examines entry strategies in the Canadian wireless discount market. Analysis was mainly focused on the incumbents' strategic choices when faced with the threat of sequential entry. The main model used is Fudenberg and Tirole's taxonomy of business strategies that is studied in the context of multimarket contact and when entry deterrence might be considered as a public good. The core of the analysis is done with two interconnected two stage games. It is argued that Fido, Solo and Virgin adopted a Puppy Dog strategy to face Koodo's entry, then might have aligned with their new competitor and switched to a Top Dog attitude when faced with the threat of a second round of market entries.

Keywords: market strategy, game theory, telecommunications, industrial organization

\footnotetext{
* I would like to first thank Professor Marcel Boyer for his great support and guidance throughout this study. I am grateful for the invaluable opportunities and exposures he provided me with during the past year. I would also want to thank Professor Jean Tirole and Assaad Farah for discussing with me conceptual matters related to this paper. And last but not least, I would like to thank the CIRANO for giving me a chance to be part of its team and work on such interesting projects.

${ }^{\dagger}$ Professionnel de recherche, sandy.mokbel@ cirano.qc.ca.
} 


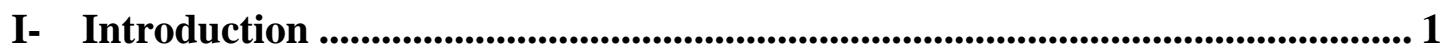

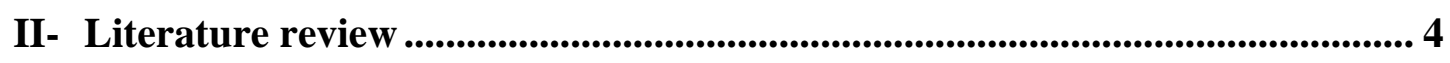

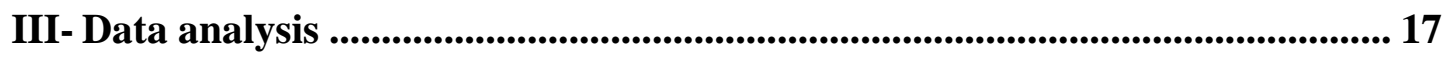

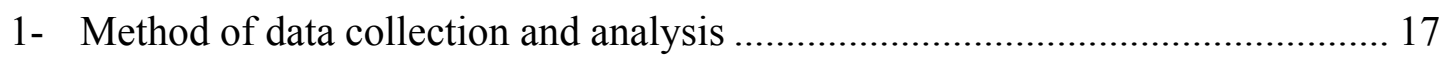

2- Capital with commitment effect in the Canadian wireless industry ................... 17

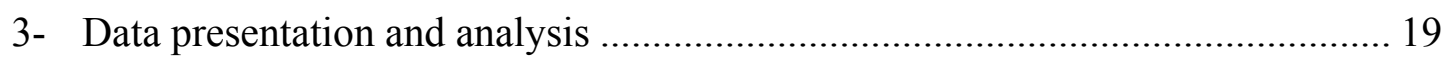

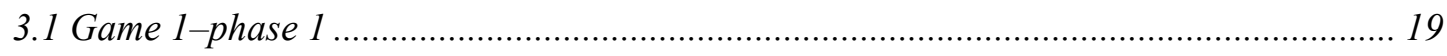

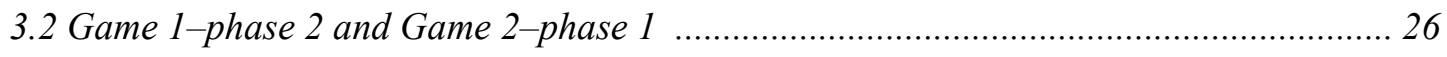

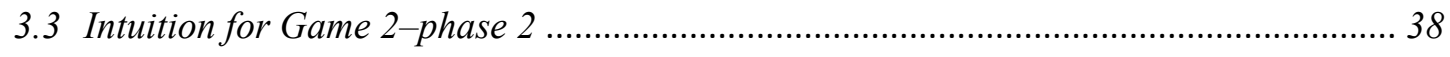

IV- Discussion and concluding remarks........................................................ 42

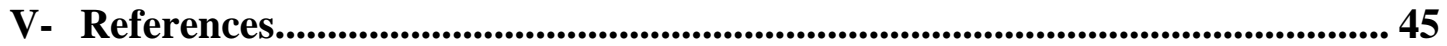




\section{I- Introduction and Research question}

The wireless industry is a highly dynamic marketplace, where continuous changes often drive firms toward acquiring novel technologies and pursuing new forms of competitive strategies. Boyer (2005) portrayed this market as an emerging one, where the number of companies and their respective market shares are not sufficient to provide a clear and straightforward picture of the level of existing competition. This being said however, the cell phone market encompasses a wide range of information that could be highly interesting for business strategy and industrial organization researchers, as well as practitioners attempting to understand the level of competitive pressures within this sector. This study is interested in examining mobile telephone competition within a specific sector and geographical setting of the wireless business, namely the post-paid Canadian discount market.

The Canadian wireless market has undergone various changes in recent years, where the post-paid discount segment gained increasing attention amongst competing companies. It is therefore sound to go over some of the events that marked this specific part of the industry.

In the late nineties, Bell, Rogers and Telus were the only cell phone providers on the Canadian territory, and were referred to as the 'big three'. The first major change came with the creation of Fido in the late nineties by a new company called Microcell Telecommunication. Fido's catchy marketing and image awarded it numerous prizes and recognition within the North American wireless industry. But what made it so successful was its pioneering move and launching of a cheaper brand that is both attractive and reliable. Despite the fact that, at that time, Fido's network only operated well in urban areas, the latter features (cheap, attractive, reliable) allowed this brand to gain a wide popularity amongst Canadians, and to become a major competitor to the older established firms.

Within its attractive packages, Fido developed a package that it offered under the name of: "City Fido", with unlimited local calling and texting for a very accessible fee. This 
bundle helped enhancing Fido's popularity, but many claim that it has plunged the organization into serious financial trouble. In fact, many analysts have claimed that this price package has been too costly on the organization and have indicated that it has plunged Fido in deep financial trouble. Within this rough period, Fido was acquired by Rogers in November $2004^{1}$. Following that, Rogers has implemented some changes within Fido in order to align it more with the big three's market approach (same structure of services: same access fees, similar structure in bundling, little talk time, no texting, etc.). Along with that, it made Fido its "discount brand", which was a first in the Canadian mobile market.

As a reaction to that, Bell quickly realized it needed to have a piece of the discount market pie. Consequently, Bell launched Solo in the summer of $2005^{2}$ which had a timid success and a modest popularity. In fact, while J.D Powers has ranked the Canadian wireless providers based on different criteria (such as: customer service, cost of service, call quality, etc.), this ranking has incorporated Solo in the Bell ranking. The fact that Solo wasn't given a separate ranking can be viewed as a sign of its relative small market size.

Virgin on the other hand, was more recently introduced to the post-paid market. It was originally an exclusively pre-paid phone provider that was owned $50 \%$ by Virgin Group and $50 \%$ by Bell. This mobile brand was highly successful in the pre-paid market and was on top of the J.D. Powers rankings for several years for the pre-paid segment. In addition, even though Virgin has only been in the post-paid market since February 2008, that didn't prevent it from gaining high marks with the JD Powers ranking. In effect, it seemed that Virgin was succeeding in every move it made. In consequence, Bell who wanted to fully take advantage of the latter company's potential went ahead and acquired $100 \%$ of Virgin mobile's shares ${ }^{3}$. This leaves Bell

\footnotetext{
${ }_{1}^{1}$ Swift, A. "Rogers prend les commandes de Fido", Le Devoir , 11-09-04.

2 BCE, press release, "Bell Canada lance un nouveau service sans fil destiné aux jeunes", 07-25-05. http://www.bce.ca/fr/news/releases/bm/2005/07/25/72567.html

${ }^{3}$ Sturgeon, J. "Bell Canada acquires 100\% of Virgin Mobile Canada", National Post, 05-07-09.
} 
with two discount brands, Solo and Virgin, competing for the same market. This poses some doubts however towards the possibility that Bell would keep on operating these two separate competing entities in the future.

Alternatively, Telus waited a while and was ready to launch its own discount brand in March $2008^{4}$, which marked the beginning of Koodo. This new Telus brand helped changing the market interactions within the discount market segment. Indeed, Koodo's bold strategy offered a new combination of bundles for relatively much lower prices, no system access fees and no committing contracts. After this entry, Fido, Solo and Virgin underwent significant mutations by dropping their system access fees and redefining their targeted market to a lower-end one. This change of strategy seemed to be triggered by Koodo's entry. Thus, my interest in understanding these interactions.

This research will therefore, first attempt to identify Koodo's entry strategies and analyse the pre-emptive moves implemented by incumbents prior to Koodo's entry. Secondly, this study will attempt to understand the post-Koodo market changes while incorporating in the analysis the anticipation of new entry.

Indeed, several newcomers are expected to enter the market as a result of governmental efforts to revive competition. In effect, in July 2008 Industry Canada organized a spectrum auction that was structured to encourage newcomers into the wireless sector. Accordingly new names in this field will soon be introduced amongst others: Globalive, Quebecor, Shaw and Saskatel will enter at a provincial or a national level.

This continuous dynamic of change may seem chaotic or ill-calculated to some, but if studied in depth, could bring sound strategic and theoretical explanations. Through the analysis and understanding of the collected data from the post-paid Canadian wireless market, this research will try to understand the strategies of incumbents and entrants by using game theory models in the economics literature.

\footnotetext{
${ }^{4}$ Bérubé, G. "Telus lance sa téléphonie à escompte”, Le Devoir, 04-01-08.
} 


\section{II- Literature review}

In a market with numerous incumbents, it is often difficult to predict the way firms will react to the threat of a new entry. With the knowledge that companies always seek to maximize their profits with respect to their constraints, it would be interesting to find explanations to some firms' market choices. In fact, several researchers attempted to understand when and why is entry deterred or accommodated. The problem's complexity is amplified when the market witnesses sequential entries, in other words, when companies enter the market before others and invest in their current activities while concurrently pre-empting new entries. In some cases, the market could seem illprepared or unaware of a new competitor's entry, but could that lack of visible preparation be in fact a well thought strategy?

Bernheim (1984), Gilbert and Vives (1986) and Waldman (1987) amongst several researchers were interested in studying entry deterrence with numerous incumbents or models with sequential entry. One of the issues addressed in those studies is linked to whether entry deterrence could be considered as a public good ${ }^{5}$. Some authors believe so and the reason is the following: if the first incumbent deters entry by accumulating a large enough amount of capital, then the remaining incumbents will also profit without paying for this project. This position is characterized by the literature as "free riding". In reference to the studied case, all incumbents will enjoy the success of a deterred entry while not necessarily having contributed to it. However, any incumbent would prefer for entry to be deterred, but it also wishes not to incur the costs needed to prevent such entry. This situation could lead to underinvestment by incumbents if explained by the classic non-cooperative subscription problem. Indeed, each incumbent wishing to deter entry is solely concerned about having to pay for a project

\footnotetext{
${ }^{5} \mathrm{~A}$ public good is a good that is non-rivalrous and non-excluable (Samuelson, 1954). In other words, non-rivalry in consumption means that consumption of one good by one individual does not reduce the availability of the good for consumption by others, each individual can therefore consume all of the available good. As for the notion of non-exclusion from consumption, it reflects the fact that no one can be excluded from using the good. Public goods are often characterized by these two properties to a certain extent, where they can have one of the two aforementioned aspects or have the two with some limitations. In fact, it is rare to find pure public goods in real life models.
} 
when there is a large number of players. An incumbent will therefore be willing to contribute less to that project when the number of beneficiaries of this project is rising. By generalizing this individual way of thinking to the entire industry, underinvestment will most probably occur. In other words, each firm will underestimate the real value of its contribution by not including the externalities of its contribution on other firms' benefits.

Let us consider that all incumbents choose their capacities simultaneously. With $K_{i}, K_{j}$ being the respective levels of capital chosen by firms " $i$ " and " $j$ ", $i$ and $j$ being the incumbent firms in this market. The potential entrant will stay out if $K_{i}+K_{j} \geq K_{B}$; with $K_{B}{ }^{6}$ being the entry-deterring level of capital in this industry. Incumbents consider deterring entry as a costly project that incurs beneficial outcomes. Each member of the present firms can undergo a portion of the costs required for deterrence to be allowed. If we consider that the individual cost to be incurred is lower than the benefit generated from the deterred entry, then everyone should be encouraging such a project. However depending on the presence or lack of cooperation between the incumbents, and, provided that the cost of deterrence cannot be borne by only one player, then underinvestment could occur. The different possible outcomes will be explained hereunder.

In the case of a simultaneous decision of the level of capital to be invested, if the right amount of capital is accumulated, the project is implemented, or in other words, deterrence is made possible. However, if too little capital is accumulated, then entry will happen. Since the price for accumulating a clientele should be at least higher than the cost of accumulating $K_{B}$ on an aggregated level, each firm would also want to incur the lowest cost for the highest level of capital accumulated. Keeping in mind that each incumbent is incurring costs by adopting this strategy, and that decision is done simultaneously, then it would be possible to witness free riding. In effect, the

\footnotetext{
${ }^{6}$ With "B" meaning "Blockaded" entry.
} 
production of public goods will generate positive externalities that anyone can benefit from, i.e. deterring entry will benefit all incumbents even if not all contributed to it due to the possibility of free riding. When an incumbent cannot benefit from all the positive outcomes of his investment, like the positive externalities generated, then incentive to invest alone might be weak. This game has therefore two pure strategy Nash equilibriums. In the first one, no one chooses to participate in the project, thus the absence of the public good's provision. In the second one, each incumbent actively decides to contribute to the project by respectively providing a fraction of the needed costs in order to produce the public good.

Accordingly, if firms cannot cooperate to agree on investing simultaneously, they would each underinvest in their own capital hoping for the other to pay the full price. In consequence, this situation would not allow for $K_{B}$ to be reached and entry won't be prevented.

A recent study conducted by Burger and Kolstad (2009) attempted to understand the incentive behind the coalition formation in the purpose of providing a public good. The study also introduced the effect of uncertainty on the decision making. The researchers used theoretical and experimental approaches to find answers to their questions. They were able to conclude that "coalitions may be more likely to form when they are most beneficial" and that subjects reduced their contribution when uncertainly in public good provision was introduced. Those latter observations could therefore explain the absence of investment in the provision of a public good, when uncertainty is high and when the outcome isn't beneficial enough to incumbent firms ${ }^{7}$.

There would also be another issue relevant in explaining the apparent lack of aggressive market preparation when threatened by upcoming market entry. In effect, Edwards (1979) with Baum and Korn (1999) discusses multimarket contact. They

\footnotetext{
${ }^{7}$ We will not consider problems of incomplete or asymmetric information, for models of that type refer to Boyer, M. and M. Moreaux (1997) and Boyer, M. and M. Moreaux (1999) and Boyer, et al. (2003).
} 
acknowledge the fact that in certain cases, firms competing against each other in various markets may be reluctant to "fight vigorously" in one market in fear of retribution attacks by competitors in other markets. Therefore, a firm should weigh in the costs and dangers of a competitor's retaliation in other markets when calculating the expected benefit of vigorous competition in one market. If such a war is declared, it could lead to a losing price battle that no one would have originally wanted. The outcome of such a war of retribution could therefore, be costly to all parties if improperly evaluated.

After presenting the previous theories with their plausible explanations to an apparent lack of effective market action to deter or limit the entrant's size, let us now go over the opposite scenario where companies decide to act otherwise ${ }^{8}$. Starting by describing the possible actions taken by the incumbent firms when faced by a threat of entry, we will follow by more complex models that capture some strategic market decisions.

For instance, if we consider a game with two players $(i=1,2)$ and with sequential moves, commitment from the first mover can be of value since it may alter the opposition's actions. Therefore, the first mover $(i=1)$ has the chance to accumulate capital before his competitor $(i=2)$. One may consider that the profits of the two firms are specified by:

$$
\Pi^{1}\left(K_{1}, K_{2}\right)=K_{1} D\left(K_{1}, K_{2}\right) \text { and } \Pi^{2}\left(K_{1}, K_{2}\right)=K_{2} D\left(K_{1}, K_{2}\right)
$$

Where " $D$ " is the market demand and where $K_{i}$ is the invested capital in each firm. Since we consider that firms operate at full capacity, then the quantity produced is equal to the invested capital. Thus $K_{i}$ is considered equivalent to the firm's production level.

\footnotetext{
${ }^{8}$ A "Real Options" analysis could also be adopted to study market choices. Indeed, Boyer, et al. (2008) introduce market analysis with real options in the presence of pre-emptive techniques. They posit that as time goes by, new information is gathered (by the firm) on the state of the environment which generates a source of options (volatility, irreversibility, flexibility). As well, as time goes by, one competitor may choose to make a move which will reduce or destroy the value of his competitors' projects. The firm will thus need to find a balance between the value of moving late (waiting) versus the value of moving early.
} 
Additionally, these profit functions need to also respect the two important properties hereunder:

1. Each firm dislikes capital accumulation by the other firms $\left(\Pi_{\mathrm{j}}^{\mathrm{i}}<0\right)$.

2. Each firm's marginal value of capital decreases with the other firm's capital level $\left(\Pi_{i j}^{i}<0\right)$.

Therefore, a player can gain from reducing his action set provided that his opponents are aware of the change. In other words, temporal asymmetry allows for the first mover to limit its opponent's capital level by accumulating more capital than it would have done in a simultaneous game. Indeed, by increasing $K_{1}$, firm 1 reduces the marginal profit from investing $\left(\Pi_{2}^{2}\right)$ for firm 2 (as long as $\Pi_{12}^{2}<0$ ), thus making firms 2 invest less to the benefit of its opponent $\left(\Pi_{2}^{1}<0\right)$. This would lead to a Stackelberg equilibrium on the one condition that capital levels are irreversible. Under this condition, capital has commitment value. In other words, if firm 1 was able to change its level of capital with time, then investing in the first period wouldn't be able to limit firm 2's capacity. It is only when the investment cost is sunk that capital could constitute a barrier to entry. Consequently, scholars have agreed on the necessity for capital investment to be difficult to reverse for it to have commitment value ${ }^{9}$. In other words, the slower the capital depreciates and the more specific it is to the firm, the stronger the commitment effect (Fudenberg and Tirole, 1991).

With the knowledge that physical capital can cause the erection of barriers to entry or limit the entrant's size, other kinds of capital may have the same effect if they have commitment value. This is something that is agreed on by Schmalensee (1983),

\footnotetext{
${ }^{9}$ Caves and Porter (1977) consider firm 1's investment with commitment value as a "barrier to mobility" since it works at reducing firm 2's scale of entry. Indeed, this theory can be illustrated by the notion of "burning bridges". This example considers two armies who wish to conquer an island located between their countries, and is also linked by a bridge to both. Let's consider that each army prefers leaving to its opponent the island instead of fighting. It is therefore considered that fighting causes losses that overcompensates any gain from controlling the island. If army 1invades the island and burns the bridge that links it to its homeland, then it is left with one less option compared to firm 2 . This leaves army 2 no choice but to let army 1 take control of the island. Indeed, army 1 is left with the only choice of fighting, since it cannot go back. This is the paradox of commitment where army 1 ends up better off after reducing its sets of choices. i.e. when firm 1 loses its mobility
} 
Baldini (1983) and Salop and Scheffman (1983). Some of the examples that were given are presented hereunder.

Firstly, learning by doing has proved to be a possible alternative by management consulting firms such as Boston Consulting Group (1972). In certain industries, experience acquired by the incumbent firms throughout their production history reduces current production costs and are therefore comparable to physical capital. Just like physical capital, learning by doing helps developing competitive advantage and consequently, could discourage entry. Especially since it hold commitment value. In effect, the experience and the knowledge of the industry that were accumulated with time cannot be deliberately forgotten. There is a strong commitment value to this type of capital that allows for a more efficient production process and higher profitability.

Additionally, developing a clientele in order to increase the demand for the firm's products can also be considered. Accordingly, some scholars claim that accumulating clients might intimidate the potential entrant, making its residual demand very low. Promotional and advertising campaigns are thus a way to attract clients by making a name out of their products but it is also a means to "pre-empt" demand. In effect, if this strategy will ensure a considerable demand for the provided product or service, then the potential demand for the entrant is weak. This however increases the demand for the provided good or service, but does not insure that those clients will remain faithful to the incumbent firm's products if a competitor enters the market. This is why firms face the need to find ways to retain their costumers even in the presence of a new competitor. This could be done by many ways. For instance firms can impose longterm contracts to their clients along with costly fees for breaking the contract or for switching to another provider. Or incumbent firms could attempt to build a web of interdependent costumers by providing a network good, this strategy could strongly discourage the incumbent's costumers to switch companies. 
Setting up a network of exclusive franchises is also a capital-related decision since it increases the entrant's distribution costs. By setting up such exclusive franchises, the incumbent will guarantee to be the sole beneficiary of the most capable suppliers' services in the market. Indeed, by initially selecting the suppliers and buyers, and, imposing exclusivity to them, the incumbent will abolish the possibility of sharing their services with its potential competitor. This leaves the potential entrant with little or no manoeuvring space, as to his choice of suppliers. Since these suppliers and buyers will be bound by long-term contracts to these franchises, this constitutes irreversibility to the status-quo and allows it to last for the duration of the contract ${ }^{10}$.

It is to be said, that attempting to understand the interactions in a market where companies seek to maximize their profits while living with the threat of entry, can be an intriguing matter. However two papers written by Fudenberg and Tirole in 1984, and Bulow et al. in 1985 were able to offer a framework of a taxonomy of business strategies with both accommodation of entry and entry deterrence as possible strategies. These two papers were presented in depth in Tirole (1988) where the models consider one incumbent (firm 1) and one entrant (firm2).

In the context of an accommodation of entry, it is considered that the incumbent firm's first-period behaviour is dictated by its own profits when it is compelled to face entry. It is to be noted that accommodation of entry occurs when deterrence is too costly.

The incumbent's incentive to invest is represented by the total derivative of:

$\Pi_{1}\left(K_{1}, x_{1}^{*}\left(K_{1}\right), x_{2}^{*}\left(K_{1}\right)\right)$ with respect to $K_{1}$

\footnotetext{
${ }^{10}$ Mascarenhas and Aaker (1989) expand these theories and base their study on the supposition that firms in a strategic group will have similar assets and skills, and that group identification should be based on mobility barriers. They find that depending on the credibility of the strategic group, the type of capital invested and the level of protection of these groups, profitability can vary considerably. They also find that Caves and Porter's "burning bridges theory" is often sought after by strategists. Indeed, strategists seek to create "entry barriers into one's group while reducing exit barriers, and also recognize that different barriers may be needed to keep out potential competitors from differentially positioned groups".
} 
Where $K_{1}$ is the level of capital chosen by the incumbent in the period prior to firm 2's entry. With $x_{1}^{*}$ and $x_{2}^{*}$ as post-entry choices that constitute a Nash equilibrium. We will consider from now on that $\left\{x_{1}^{*}\left(K_{1}\right), x_{2}^{*}\left(K_{1}\right)\right\}$ is a unique and stable Nash equilibrium.

Considering that the effect of a variation in the second-period action on $\Pi_{1}$ is of the second order, then from the envelope theorem Bulow et al.(1985) found:

$$
\frac{d \Pi_{1}}{d K_{1}}=\frac{\partial \Pi_{1}}{\underbrace{\partial K_{1}}_{\begin{array}{c}
\text { Direct } \\
\text { effect }
\end{array}}}+\underbrace{\frac{\partial \Pi_{1}}{\partial x_{2}} \frac{d x_{2}^{*}}{d K_{1}}}_{\begin{array}{c}
\text { Strategic } \\
\text { effect }
\end{array}}+\underbrace{\frac{\partial \Pi_{1}}{\partial x_{1}} \frac{d x_{1}}{d K_{1}}}_{=0}
$$

Since $\frac{\partial \Pi_{1}}{\partial x_{1}}=0$

As a result, this derivation can be analyzed with two distinct effects. Bulow et al. considered therefore $\frac{\partial \Pi_{1}}{\partial K_{1}}$ as the "Direct effect" or "Cost minimizing effect" and $\left(\frac{\partial \Pi_{1}}{\partial x_{2}} \frac{d x_{2}^{*}}{d K_{1}}\right)$ as the "Strategic effect".

The first effect is to be ignored in this analysis since it would exist even in the absence of firm 2's threat and therefore wouldn't affect $x_{2}^{*}$. The strategic effect is however much more interesting to study since it results from the influence of the entrant's second-period reaction. In other words, firm 1 should underinvest if the strategic effect is negative, and oversinvest otherwise.

The sign of the strategic effect is linked to two factors: first it is related to the effect of investment on the incumbent's projected image (in other words, if investment makes firm1 look "tough" or "soft"), and second, it is affected by the slope of the secondperiod reaction curve. In order to simplify this analysis without loss of generality, the authors have considered that both the incumbent and entrant have the same sign of $\frac{\partial \Pi_{1}}{\partial x_{2}}$ 
and $\frac{\partial \Pi_{2}}{\partial x_{1}}$. We will consider for now that second-period competition is in prices so that $\frac{\partial \Pi_{i}}{\partial x_{j}}>0$ (it would be $\frac{\partial \Pi_{i}}{\partial x_{j}}<0$ if second-period competition was is quantity).

Using the fact that

$$
\frac{d x_{2}^{*}}{d K_{1}}=\left(\frac{d x_{2}^{*}}{d x_{1}}\right)\left(\frac{d x_{1}^{*}}{d K_{1}}\right)=\left[R_{2}^{\prime}\left(x_{1}^{*}\right)\right] \cdot\left(\frac{d x_{1}^{*}}{d K_{1}}\right)
$$

and by keeping in mind that $\frac{\partial \Pi_{1}}{\partial x_{2}}$ and $\frac{\partial \Pi_{2}}{\partial x_{1}}$ have the same sign, by applying the chain rule and rearranging, the authors have found that:

$$
\operatorname{sign}\left(\frac{\partial \Pi_{1}}{\partial x_{2}} \frac{d x_{2}^{*}}{d K_{1}}\right)=\operatorname{sign}\left(\frac{\partial \Pi_{2}}{\partial x_{1}} \frac{d x_{1}^{*}}{d K_{1}}\right) \times \operatorname{sign}\left(R_{2}^{\prime}\right)
$$

Fudenberg and Tirole gave an animal terminology to build the taxonomy of business strategies. They consider the following four strategic behaviours and give them animal-like illustrations. They indicate that acting as a:

- Top Dog is done to be big and strong to look tough and aggressive

- Puppy Dog is done to be small or weak to look soft or inoffensive

- Lean and Hungry is done to be small or weak to look tough or aggressive

- Fat Cat is done to be big or strong to look soft or inoffensive

In effect, the literature distinguishes four cases depending on whether second-period actions are strategic substitutes or complements (i.e. if reaction functions are downward or upward sloping). Either way, the incumbent always tries to induce a softer behaviour from the entrant through its investment strategies.

Consider that investment makes the incumbent:

tough if $\frac{d \Pi_{2}}{d K_{1}}<0$

and

soft if $\frac{d \Pi_{2}}{d K_{1}}>0$. 
The following states the four cases distinguished by the literature:

1. If investment makes firm 1 tough and the reaction curves are downward slopping, investment by firm 1 induces a softer action by firm 2 . Therefore, firm 1 should overinvest for strategic purposes (i.e. should follow the "top dog" strategy).

2. If investment makes firm 1 tough and the reaction curves are upward sloping, firm 1 should underinvest (the "puppy dog" strategy) so as not to trigger an aggressive response from firm 2.

3. If investment makes firm 1 soft and the reaction curves are downward sloping, firm 1 should stay "lean and hungry".

4. If investment makes firm 1 soft and the reaction curves are upward sloping, firm 1 should overinvest to become a "fat cat".

Considering that prices are strategic complements and quantities are strategic substitutes, then a reduction in marginal cost reduces firm 1's prices in the price game and increases firm 1's output in the quantity game.

In the case of deterrence of entry, firm 1 would want to adopt a strategy based on its choice of $K_{1}$ in order to make firm 2's entry unprofitable. Therefore, firm 1 will chose $K_{1}$ in a way that allows for the following:

$$
\Pi^{2}\left(K_{1}, x_{1}^{*}\left(K_{1}\right), x_{2}^{*}\left(K_{1}\right)\right)=0
$$

To uncover the strategy that will be adopted by firm 1, it is important to understand the effect of $K_{1}$ on $\Pi_{2}$. Considering that:

$$
\frac{\partial \Pi_{2}}{\partial x_{2}}\left(K_{1}, x_{1}^{*}\left(K_{1}\right), x_{2}^{*}\left(K_{1}\right)\right)=0
$$

that is, applying the envelope theorem stating that firm 2's second period choice should be ignored, then only two terms remain:

$$
\frac{d \Pi_{2}}{d K_{1}}=\underbrace{\frac{\partial \Pi_{2}}{\partial K_{1}}}_{\begin{array}{c}
\text { Direct } \\
\text { effect }
\end{array}}+\underbrace{\frac{\partial \Pi_{2}}{\partial x_{1}} \frac{d x_{1}^{*}}{d K_{1}}}_{\begin{array}{c}
\text { Strategic } \\
\text { effect }
\end{array}}+\underbrace{\frac{\partial \Pi_{2}}{\partial x_{2}} \frac{d x_{2}^{*}}{d K_{1}}}_{=0}
$$


In this situation, the direct effect on $\Pi_{2}$ from the variation of $K_{1}$ can be negative (if capital is in a form an accumulated clientele) or null (if capital takes the form of a capacity or a technique). The strategic effect comes from the fact that the choice of $K_{1}$ will change firm 1 's second period behaviour $\left(d x_{1}^{*} / d K_{1}\right)$ and consequently impact firm 2's profits (in proportion to $\partial \Pi_{2} / \partial x_{1}$ ). Therefore the total effect of $K_{1}$ on $\Pi_{2}$ comes form the sum of the two effects.

Consider that investment makes the incumbent:

tough if $\frac{d \Pi_{2}}{d K_{1}}<0$

and

soft if $\frac{d \Pi_{2}}{d K_{1}}>0$.

In the case where the incumbent wants to deter entry, he would want to look tough. Hence, if investment makes firm 1 look tough, then it should "overinvest", thus use the "top dog" strategy. However if investment makes it look soft, then firm 1 will need to "underinvest" i.e. stay lean and hungry in order to prevent the entry of firm 2.

This model can therefore enable the understanding of entry strategies according to the analysis of firm 1's first period behaviour and the nature of post-entry competition depending on the incumbent's choice to deter or accommodate entry. Fudenberg and Tirole's model with heir animal terminology can be summarized in the following table $^{11}$.

\footnotetext{
${ }^{11}$ Fudenberg, D., and J. Tirole. 1984. The fact cat effect, the Puppy Dog Ploy and the Lean and Hungry Look. American Economic Review, Papers and Proceedings 74: 361-368.
} 


\begin{tabular}{|c|c|c|}
\hline & \multicolumn{2}{|c|}{ Investment makes firm 1} \\
\hline & $\begin{array}{c}\text { Tough } \\
\left(\frac{d \Pi_{2}}{d K_{1}}<0\right)\end{array}$ & $\begin{array}{c}\text { Soft } \\
\left(\frac{d \Pi_{2}}{d K_{1}}>0\right)\end{array}$ \\
\hline $\begin{array}{l}\text { Strategic Complements } \\
\left(\mathrm{R}^{\prime}>0\right) \\
\text { (i.e. price competition) }\end{array}$ & $\begin{array}{l}\text { A: Puppy Dog } \\
\text { D: Top Dog }\end{array}$ & $\begin{array}{c}\text { A: Fat Cat } \\
\text { D:Lean and Hungry }\end{array}$ \\
\hline $\begin{array}{l}\text { Strategic Substitutes } \\
\left(\mathrm{R}^{\prime}<0\right) \\
\text { (i.e. quantity competition) }\end{array}$ & $\begin{array}{l}\text { A and D } \\
\text { Top Dog }\end{array}$ & $\begin{array}{c}\text { A and D } \\
\text { Lean and Hungry }\end{array}$ \\
\hline
\end{tabular}

Note: A= Accommodation; D: Deter entry

Since the publication of Fudenberg and Tirole's taxonomy of business strategies, several researchers added to this model empirical and theoretical expansions. For instance, Tombak (2005) used the model to understand the strategic interactions between Boeing (the incumbent) and Airbus (the entrant) into the commercial jumbo jet market. Tombak recalls Airbus's announcement of the A330's launching which was "to compete with Boeing's 747 on medium to long-range routes". In consequence of that announcement, Boeing chose to accommodate entry, and then overinvested in areas that would make it tough (increased spending on new aircrafts and on airframes modifications) and underinvest in areas that would make it soft (reduced spending on R\&D), thus, adopting the Top Dog and Lean and Hungry strategy in spite of a vigorous price competition (that lead to accusations of dumping). This choice of action contradicts Fudenberg and Tirole's model, since when entry is accommodated, and 
when investment makes firm 1 tough, if second-period competition is in prices, the incumbent should underinvest to look like a Puppy Dog in order to induce a softer behaviour from the entrant and should overinvest in capital that would make it soft in order to appear as a Fat Cat. Tombak ingeniously explained this apparent contradiction by a significant difference in production efficiency of Jumbo jet aircrafts between the two providers. Indeed, Boeing's long-term experience in building such carriers allowed it to have lower production costs than the newcomer in the market. This lead to a reaction function in prices that was downward sloping for Boeing and upward sloping for Airbus. Thereby, leaving Boeing to accommodate entry in price competition by optimally overinvesting in capital that made it tough (Fat Cat) and underinvesting in capital that made it look soft (Puppy Dog). Tombak's intuition for this result is: "that Boeing could not prevent entry but in accommodating tried to thwart Airbus from gaining volume as that would allow Airbus to go down the learning curve, lower its unit costs, and make Airbus into a more aggressive price competitor in the future".

We have reviewed in this chapter three global models that could depict some aspects of market interactions. The first one presents entry deterrence as a public good, the second considers aggressive behaviour under price competition in a multimarket competition, and the third model offered a taxonomy of business strategies in accommodation and deterrence of entry. We have highlighted as well the importance of investment in various forms of capital with commitment value. Let us now look at the latest changes in Canada's wireless discount market. We will choose to present the collected data then attempt to understand the reasons behind the major strategies that were adopted in that industry. 


\section{III- Data Analysis}

\section{1- Method of data collection and analysis}

This research is primarily based on collected data from Fido and Koodo as well as on an interview with a strategic consultant to Bell who wishes to remain anonymous. I also approached the former two companies (Fido and Koodo) and was given access to their archived brochures dated from January 2008 until August 2009 (all provided data was public and no confidential information was presented to me). As for the information regarding the remaining incumbents such as Solo and Virgin Mobile, it was collected from their respective stores (in the form of brochures) and from newspaper articles. The gathered data was then meticulously compared and analysed in an attempt to understand the competitive interactions in the Canadian discount market. As a result, the researcher was able to generate the subsequent model that could explain the interactions in this industry.

\section{2-Capital with commitment effect in the Canadian wireless industry}

Let us start by characterizing the types of capital with commitment value in the considered industry. As we might recall, capital invested isn't necessarily a physical one. In effect, Schmalensee (1983), Baldini (1983) and Salop and Scheffman (1983) showed that other kinds of capital may have the same effect if they have commitment value. Therefore, Fido's market experience along with its strategic objective to expand its client base could both be considered as equivalent to accumulating capital. Indeed, experience accumulated with time from operating in a certain market, can reduce current production costs.

Learning by doing generates a competitive advantage which sends the signal that this company is here to stay. This commitment to the market by the incumbent could discourage entry. In effect, the experience gained from operating in a market such as this one, can allow for a better understanding of the market demand, allow for a better management of the firm's operations and have relatively more efficient methods of production, this can help the company in better attracting and retaining its customer 
base. Therefore, since knowledge cannot be destroyed or deliberately forgotten, it has significant a commitment value to the market.

Moreover, developing a clientele will increase the demand for the firm's products, leaving a relatively smaller residual demand to its potential competitor. This latter form of capital is mainly based on a combination of two sets of strategies. The first set is used to attract the clientele; as for the second set, it is used to retain those customers. In other words, Fido relies mostly on advertising campaigns to attract it customers. Its massive marketing campaigns, along with its advertising strategies, shaped a widely known product in the market. This strategy allowed the building of Fido's name, thus making its products attractive for new clients who already felt familiar and comfortable with this brand. This is a way to "pre-empt" demand as presented in the literature.

Fido also relies a lot on network formation to both attract and retain its clients. Indeed, Fido offers $\$ 20$ for their current clients who refer new customers to Fido. The new customer will also benefit from this referral as he will also receive $\$ 20$. This system creates an incentive for Fido's customers to encourage their friends to chose this supplier. Fido also offers the $\$ 10$ "Fido to Fido" option that allows for unlimited talking and texting among Fido subscribers at all times of the day. This widely popular option generates a web of interdependent customers who are made loyal to their provider because of their need to belong to this network. Therefore, a potential client whose friends are mostly clients of Fido, will have a strong incentive in joining this network of interdependent clients in order to get the most services for the offered market price.

Furthermore, Fido works on retaining its customers on several other levels. For instance it encourages its clients to sign long-term contracts with their wireless provider in exchange of additional services and options. Fido also offers what they call "Fido Dollars" which are points accumulated with time as a client of Fido. This latter system is found to promote customer loyalty as they are able to accumulate more 
points (i.e. "Fido Dollars") the more they remain with their provider. Those "dollars" could then be used to buy a new phone or new phone accessories.

\section{3- Data presentation and analysis}

Having described some characteristics of the Canadian wireless discount market, we will now go over the gathered data. Presenting, comparing and analyzing the information available allowed us to develop a particular model specific to this market. The following analysis is thus divided in two consecutive two-stage games. The first game will allow for a better understanding of Koodo's entry strategies. The second game will try to depict the entry strategies of new license holders. In both cases, analysis will attempt to explain how the incumbents were preparing for the upcoming change. It will also present the reasons behind the market interactions that incurred post each entry.

\subsection{Game 1 - Phase 1}

When Koodo was introduced to the market in March 2008, Fido had already issued its pricing plans in February 2008 for the upcoming semester.

\begin{tabular}{|l|c|c|c|}
\multicolumn{1}{l}{ Table 1 } & $\begin{array}{c}\text { Fido } \\
\text { (Feb 08) }\end{array}$ & $\begin{array}{c}\text { Kodoo } \\
\text { (March 08) }\end{array}$ & $\begin{array}{c}\text { Kodoo } \\
\text { (March 08) }\end{array}$ \\
\hline Announced package price & $\$ 20$ & $\$ 15$ & $\$ 25$ \\
\hline $\begin{array}{l}\text { Effective package price (with } \\
\text { system access fee and 911 fees) }\end{array}$ & $\$ 27.45$ & $\$ 15$ & $\$ 25$ \\
\hline Anytime Minutes & 200 & 50 & 100 \\
\hline Text Messages & $\mathbf{x}$ & 50 & 50 \\
\hline $\begin{array}{l}\text { Unlimited Evenings and Week- } \\
\text { ends at 7pm }\end{array}$ & $\mathbf{x}$ & $\mathbf{x}$ & $\checkmark$ \\
\hline Call Waiting & $\checkmark$ & $\checkmark$ & $\checkmark$ \\
\hline Conference Call & $\mathbf{r}$ & $\checkmark$ & $\checkmark$ \\
\hline Call Forwarding & & & $\checkmark$ \\
\hline
\end{tabular}

\footnotetext{
${ }^{12}$ This option allows for unlimited talk and text messaging from $7 \mathrm{pm}$ to 8 am on weekdays from Monday to Thursday and from Friday at $7 \mathrm{pm}$ to Monday at $8 \mathrm{am}$.
} 
Fido's cheapest plan was announced to be at $\$ 20$, but after the addition of the system access fees, it reached \$27.45/month before tax and offered 200 minutes of anytime calling minutes with call waiting and conference call. In Fido's February brochure, no add-on option for text messaging was available. It was only possible to acquire messaging options through bundles that offered other add-on services. Whereas Koodo's cheapest bundle was offered at $\$ 15 /$ month and included: 50 minutes of talk time, 50 text messages per month, call waiting, call forwarding and conference call. There also was the $\$ 25$ bundle offered by Koodo, which was cheaper than Fido's $\$ 27.45$ package and offered more flexible options. Therefore, by allowing for 100 less minutes of talk time, Koodo gave its clients the possibility to talk unlimitedly after $7 \mathrm{pm}$ on weeknights and weekends on top of granting 50 text messages.

Let us consider a potential customer who is indifferent between going with Fido or Koodo, doesn't have any preference as to the type of phones that are offered by each company nor does $\mathrm{s} / \mathrm{he}$ care much for any of the two technologies used. A customer that is solely interested in getting the best product for the given price won't necessarily have an obvious choice between Fido or Koodo in the beginning of 2008. Along with offering lower prices than Fido, Koodo also offered mostly a different variety of services. As a result, a potential customer that favours a low-cost wireless phone with limited talk time and more texting options, would have probably chosen Koodo. However, product differentiation is used to attract various types of customers with different needs and tastes. For instance, people interested in "couples bundles" or the "Fido to Fido" package might still be willing to acquire those relatively more costly offers because they best fit with their tastes and needs. The same goes for the ones that want more talking time during the day, those might chose Fido's $\$ 27.45$ bundle over Koodo's \$25 package. Therefore, lower prices don't necessarily give an obvious choice to all potential customers.

As a result, it appears that during the phase between March 2008 and November 2008, Fido and Koodo, were mostly aiming at different types of costumers, however Koodo hit a notable part of Fido's targeted clientele. As well, Koodo involuntarily hurt its 
mother company Telus by attracting part of Telus's targeted clientele. Indeed, some potential Telus customers might have chosen Koodo as their provider. This involuntary reaction can be described by market analysts as a "cannibalization effect".

But how can Fido's reaction to Koodo's entry be described, especially since part of Fido's clientele was being attracted by that "trendy" new brand? It was observed that within the next 2 semesters, it issued 2 brochures with minor changes. That lasted until November 2008 when Fido finally changed its strategy. It took 8 months for Fido to reveal its new plans which mainly consisted in following Koodo's steps. Indeed, as it will be discussed more in depth in the subsequent pages, Fido changed its image and marketing strategy, restructured its packages and redirected its targeted market to a lower-end one.

The logical next step of the analysis would be to uncover if the "discount market" was awaiting Koodo's entry and if it prepared appropriately for it? Following an interview with a consultant to Bell (who wishes to remain anonymous), it was found that Koodo's timing and its aggressive marketing were indeed a surprise to the industry. However the market was aware that Telus was eventually going to launch a "discount brand". In effect, following Rogers' acquisition of Fido, Bell launched its own discount brand: Solo. Consequently, this made Telus the only company without a "discount brand". So this leads to the supposition that the incumbent firms were aware of the upcoming threat, but didn't know when Telus was going to strike. It is also to be noted that Koodo's marketing strategy came as a shock to the industry. Koodo bluntly based its image on mocking the incumbent firms; a much unexpected approach since Koodo was itself affiliated to one of the big three. As cited earlier, this bombshell led to a "cannibalization effect" within the Telus Corporation.

However, how can the lack of significant market change prior to Koodo's entry be explained? Even if Telus was preparing for Koodo's launch under complete secrecy, the remaining incumbents still expected a certain upcoming action from Telus. 
Therefore, could their apparent lack of pre-emptive actions reveal a costly and illprepared strategy?

Some analysts might think not, especially since dropping the system access fees and redirecting the targeted market to a lower-end one might result in lowering the profit per customer. In fact, basing our analysis on Bernheim(1984) along with Gilbert and Vives (1986) and Waldman (1987), when deterrence is associated to a public good, all incumbents will enjoy the success of a deterred entry while not necessarily having contributed to it. As indicated previously, since, any incumbent would prefer for entry to be deterred, it also wishes not to incur the costs needed to prevent such entry. This situation could lead to underinvestment by Fido, Solo and Virgin mobile, if explained by the classic non-cooperative subscription problem. An incumbent will therefore be willing to contribute less to that project when the number of beneficiaries of this project is rising. Since there are three incumbents in that market, underinvestment will most probably occur by each of Fido, Solo and Virgin mobile. In other words, each firm will underestimate the real value of its contribution by not including the externalities of each contribution on the other firms' contribution.

In an attempt to explain why Fido, Solo and Virgin kept their system access fees and higher prices, let's consider that all incumbents chose their capacities simultaneously. With $K_{F}, K_{S}$ and $K_{V}$ being the respective levels of capital chosen by Fido, Solo and Virgin, the potential entrant will stay out if $K_{F}+K_{S}+K_{V} \geq K_{B}$ with $K_{B}$ being the entry-deterring industry capacity.

If we consider for now that incumbents interact in a Stackelber competition with Fido as a market leader and Solo and Virgin as market followers, they will chose sequentially how much to invest in their capital (that has commitment value). Thus, if the right amount of capital is accumulated, the project is implemented, or in other words, deterrence is made possible. However, if too little capital is accumulated, then entry will occur. Since for instance, the price for accumulating a clientele should be at least higher than the cost of accumulating $K_{B}$ on an aggregated level, each firm would also want to incur the lowest cost for the highest level of capital accumulated. It would 
be possible to witness a "free riding" problem, where each incumbent would depend on others to spend more while it is benefiting from the positive outcome of a deterred entry. Indeed, if incumbents do not choose to change their market strategy to counter the threat of entry, they will not only avoid spending in capital accumulation, they will also have more time to benefit from relatively high profit per client - at least until Koodo enters and triggers some market changes. In other words, Fido, Solo and Virgin would each underinvest in their own capital hoping for others to pay the full price, while making the best of their last chances to generate supranormal profits per clients. However, this would not allow for $K_{B}$ to be reached and entry won't be prevented.

Considering that Fido is a market leader with the most influence on the market it would be the first to take a position whether to invest or not for deterring entry. Its choice of investment will most probably not be enough to discourage a threat of entry. As for its market followers, Solo and Virgin will chose to underinvest as well. As a result $K_{B}$ won't be attained. If we complete this analysis with the introduction of uncertainty regarding the timing of Koodo's entry and if we consider that Koodo's success in establishing itself in the market was also uncertain, then the benefits of forming a coalition (if possible even if illegal) amongst Fido, Solo and Virgin couldn't be clearly evaluated in phase one of game one. This would result in backing up the original conclusion that there are high chances of not implementing the project, i.e. deterrence won't be realised. The public good theory could therefore be a plausible explanation as to the apparent negligible preparation of the incumbents firms in the Canadian "discount market".

Other authors could try to explain this situation otherwise. If we refer to Corwin Edwards' thoughts on multimarket contact, one could consider that firms competing against each other in various markets may be reluctant to "fight vigorously" in one market in fear of retribution attacks by competitors in other markets. This theory could explain the incumbent's concerns prior to Koodo's entry. Given that Fido, Solo and Virgin are all affiliated to higher entities that operate on various markets, it would have 
subsequently been risky to trigger a war in the "discount market" fearing retaliation raids in the "higher-end market". This could have led to a losing war that no one would have wanted to take part in.

These two sets of ideas could be valid arguments in justifying the phase before Koodo's entry. All of these factors could also be coupled with the optimal business strategies discussed in Fudenberg and Tirole (1984), and Bulow, et al. (1985). However, their model considers one incumbent and one entrant. But since it is a Stackelberg competition where Fido is a leader and Solo and Virgin are its followers, then it could be acceptable to consider the above-mentioned market interaction to explain the studied case. Fido is the decision-maker thus it is the one that shapes the market's directions.

Keeping in mind that Fido was aware that Telus would eventually launch a competing discount brand, let's consider Fido's first-period behaviour as the period before Koodo's entry, and the market's second-period behaviour as the one following Koodo's entry.

By revisiting the theory that illustrates an accommodation of entry, it is considered that the incumbent firm's first-period behaviour is dictated by its own profits when it is compelled to face entry.

Fido's incentive to invest is embodied in the total derivative of :

$\Pi_{F}\left(K_{F}, x_{F}^{*}\left(K_{F}\right), x_{O}^{*}\left(K_{F}\right)\right)$ with respect to $K_{F}$

Where $K_{F}$ is the level of capital chosen by Fido in the first-period of the game. With $x_{F}^{*}$ and $x_{O}^{*}$ as post-entry choices of Fido and Koodo respectively that are determined by a Nash equilibrium.

We will consider from now on that $\left\{x_{F}^{*}\left(K_{F}\right), x_{O}^{*}\left(K_{F}\right)\right\}$ is a unique and stable Nash equilibrium. 
Considering that the effect of a variation in the second-period action on $\Pi_{F}$ is of the second order, then from the envelope theorem that gives us $\frac{\partial \Pi_{F}}{\partial x_{F}}=0$, Bulow et al.(1985) found:

$$
\frac{d \Pi_{F}}{d K_{F}}=\frac{\partial \Pi_{F}}{\underbrace{\partial K_{F}}_{\begin{array}{c}
\text { Direct } \\
\text { effect }
\end{array}}}+\underbrace{\frac{\partial \Pi_{F}}{\partial x_{O}} \frac{d x_{O}^{*}}{d K_{F}}}_{\begin{array}{c}
\text { Strategic } \\
\text { effect }
\end{array}}+\underbrace{\frac{\partial \Pi_{F}}{\partial x_{F}} \frac{d x_{F}}{d K_{F}}}_{=0}
$$

where this derivation can be analyzed as two distinct effects. Therefore, let me recall that Bulow et al. considered $\frac{d \Pi_{F}}{d K_{F}}$ as the "Direct effect" or "Cost minimizing effect" and $\frac{\partial \Pi_{F}}{\partial x_{F}}$ as the "Strategic effect".

In reference to what was previously presented in that model, the first effect is to be ignored in the analysis since it would exist even in the absence of Koodo's threat and therefore wouldn't affect $x_{O}^{*}$. The strategic effect is however much more interesting to study since it results from the influence of Koodo's second-period reaction.

In other words, Fido should underinvest if the strategic effect is negative and oversinvest otherwise.

The sign of the strategic effect is linked to two factors: first it is related to the effect of investment on the incumbent's projected image (in other words, if investment makes Fido look "tough" or "soft"), and second, it is affected by the slope of the secondperiod reaction curve. In order to simplify this analysis without loss of generality, the authors have considered that both incumbent and entrant have the same sign of $\frac{\partial \Pi_{F}}{\partial x_{O}}$ and $\frac{\partial \Pi_{O}}{\partial x_{F}}$. Let's consider for now that second-period competition is in prices therefore $\frac{\partial \Pi_{i}}{\partial x_{j}}>0$.

Straightforward transformations lead to the following relation: 


$$
\operatorname{sign}\left(\frac{\partial \Pi_{F}}{\partial x_{O}} \frac{d x_{F}^{*}}{d K_{F}}\right)=\operatorname{sign}\left(\frac{\partial \Pi_{O}}{\partial x_{F}} \frac{d x_{F}^{*}}{d K_{F}}\right) \times \operatorname{sign}\left(R_{O}^{\prime}\right)
$$

This relation distinguishes four cases depending whether second-period actions are strategic substitutes or complements (i.e. if reaction functions are upward or downward sloping). Either way, the incumbent always tries to induce a softer behaviour from the entrant through its investment strategies. Having considered that investment makes the incumbent

tough if $\frac{d \Pi_{O}}{d K_{F}}<0$

or

soft if $\frac{d \Pi_{O}}{d K_{F}}>0$.

In the postpaid wireless discount market, any of the incumbents will look tough if investment in capital is undergone. Indeed, as explained in the previous sections, accumulating different forms of capital with commitment value could induce tougher reactions from the newcomer. In addition to that, subsequent analysis of competition in the second-phase has revealed that competition was most probably based around prices. Thus revealing that competition is made among strategic complements (i.e. $\left.R^{\prime}>0\right)$.

It is therefore plausible to consider Fido's optimal business strategy prior to Koodo's entry as a "puppy dog".

\subsection{Game 1 - Phase 2 and Game 2 - Phase 1}

It would be now interesting to move to the next step of the analysis and attempt to model Fido's market decisions during phase 2 of game 1. In order to do so, we should take a closer look at the data available during this phase; specifically to the time of Fido's sensible change in November 2008. Fido's strategic move was reproduced a few days later by similar reactions from its followers. Indeed, Fido along with Solo 
and Virgin dropped the 911 emergency fee and the system access fee and were now all applying a per-second billing. In fact, Fido's cheapest bundle became available at \$15/month including 50 anytime calling minutes, 50 text messages sent from Canada to a Canadian wireless number, call waiting and conference call which comes with a one-time activation fee of $\$ 25$ to $\$ 35$. As for Koodo's $\$ 15 /$ monthly bundle, it covers call waiting, conference call as well as 50 minutes of anytime talking and 50 text messages; and did that with no activation fee. So if it weren't for Fido's activation fee, the offers would have been the same.

$\underline{\text { Table } 2}$

\begin{tabular}{|c|c|c|c|c|c|c|c|c|}
\hline Package & $\begin{array}{l}\text { Fido } \\
\text { (Nov } \\
\text { 08) }\end{array}$ & \begin{tabular}{|c|} 
Kodoo \\
(Nov \\
$08)$
\end{tabular} & $\begin{array}{l}\text { Fido } \\
\text { (Nov } \\
\text { 08) }\end{array}$ & $\begin{array}{c}\text { Kodoo } \\
\text { (Nov } \\
08)\end{array}$ & $\begin{array}{c}\text { Fido } \\
\text { (Nov 08) }\end{array}$ & $\begin{array}{l}\text { Kodoo } \\
\text { (Nov 08) }\end{array}$ & $\begin{array}{c}\text { Fido } \\
\text { (Nov 08) }\end{array}$ & $\begin{array}{l}\text { Kodoo } \\
\text { (Nov 08) }\end{array}$ \\
\hline $\begin{array}{l}\text { Announced } \\
\text { package } \\
\text { price }\end{array}$ & \multicolumn{2}{|c|}{$15 \$$} & \multicolumn{2}{|c|}{$\$ 20$} & \multicolumn{2}{|c|}{$\$ 25$} & \multicolumn{2}{|c|}{$\$ 70$} \\
\hline $\begin{array}{l}\text { Activation } \\
\text { Fee }\end{array}$ & $\begin{array}{c}\$ 25 \text { or } \\
\$ 35\end{array}$ & $x$ & $\begin{array}{c}\$ 25 \text { or } \\
\$ 35\end{array}$ & $x$ & $\begin{array}{c}\$ 25 \text { or } \\
\$ 35\end{array}$ & $x$ & $\begin{array}{c}\$ 25 \text { or } \\
\$ 35\end{array}$ & $x$ \\
\hline $\begin{array}{l}\text { Anytime } \\
\text { Minutes }\end{array}$ & 50 & 50 & 50 & 100 & 100 & 100 & 2,000 & 2,000 \\
\hline $\begin{array}{l}\text { Text } \\
\text { Messages }\end{array}$ & 50 & 50 & 50 & $50 *$ & Unlimited & Unlimited $* *$ & Unlimited & Unlimited ${ }^{* *}$ \\
\hline $\begin{array}{l}\text { Unlimited } \\
\text { Evenings } \\
\text { and Week- } \\
\text { ends at } 7 \mathrm{pm}\end{array}$ & $x$ & $x$ & $\checkmark$ & $\checkmark$ & $\checkmark$ & $\checkmark$ & $\checkmark$ & $\checkmark$ \\
\hline Call Waiting & $\checkmark$ & $\checkmark$ & $\checkmark$ & $\checkmark$ & $\checkmark$ & $\checkmark$ & $\checkmark$ & $\checkmark$ \\
\hline $\begin{array}{l}\text { Conference } \\
\text { Call }\end{array}$ & $\checkmark$ & $\checkmark$ & $\checkmark$ & $\checkmark$ & $\checkmark$ & $\checkmark$ & $\checkmark$ & $\checkmark$ \\
\hline
\end{tabular}


Similar packages were also seen during that semester with slight differentiations. At all times Fido had an activation fee, which Kodoo didn't require. Kodoo seemed to generally offer more services than Fido for the same price. Indeed, as seen in Table 2, for the $20 \$$ bundle, Kodoo gave 50 additional minutes and allowed for local and international text messaging. As for the $25 \$$ and $70 \$$ packages, Kodoo offered the same range of services with an extra option that allows for local and international text and picture messaging.

A clear difference is however noticed in Koodo's advantage when comparing Koodo's $\$ 30 /$ month plan with Fido's \$35/month plan. In fact, Koodo offered for $5 \$$ less an additional 50 minutes of talk time and offered its messaging option for local and international texts and pictures. On the other hand, Fido offered for a higher price and a one-time activation fee less talk time, same unlimited evening and weekend option but only local unlimited text only option. The same package superiority is seen when comparing Kodoo's $45 \$$ offer to Fido's $50 \$$ one. Here also, Kodoo seems to offer more talk time (150 extra minutes), more sophisticated texting services without an activation fee.

Table 3

\begin{tabular}{|l|c|c|c|c|}
\hline Package & $\begin{array}{c}\text { Fido } \\
\text { (Nov 08) }\end{array}$ & $\begin{array}{c}\text { Kodoo } \\
\text { (Nov 08) }\end{array}$ & $\begin{array}{c}\text { Fido } \\
\text { (Nov 08) }\end{array}$ & $\begin{array}{c}\text { Kodoo } \\
\text { (Nov 08) }\end{array}$ \\
\hline $\begin{array}{l}\text { Announced package } \\
\text { price }\end{array}$ & $\$ 35$ & $\$ 30$ & $\$ 50$ & $\$ 45$ \\
\hline Activation Fee & $\$ 25$ or \$35 & $\mathbf{x}$ & $\$ 25$ or \$35 & x \\
\hline Anytime Minutes & 250 & 300 & 600 & 750 \\
\hline Text Messages & Unlimited & Unlimited** & Unlimited & Unlimited** \\
\hline $\begin{array}{l}\text { Unlimited Evenings and } \\
\text { Week-ends at 7pm }\end{array}$ & $\checkmark$ & $\checkmark$ & $\checkmark$ & $\checkmark$ \\
\hline Call Waiting & $\checkmark$ & $\checkmark$ & $\checkmark$ & $\checkmark$ \\
\hline Conference Call & $\checkmark$ & $\checkmark$ & $\checkmark$ & $\checkmark$ \\
\hline
\end{tabular}

**this option is valid for local and international text and picture messaging 
Untill now the data we presented seem to favour Kodoo's offers if we were to rely on the decision criteria adopted at the beginning of this analysis. For seemingly similar prices, Kodoo could be more attractive to new clients.

This situation might be read as a direct price competition with relatively homogenous services that could lead to a losing price war and a Bertand equilibrium.

However not all packages seem so homogeneous. In fact, both Fido and Kodoo made sure to keep 2 respectively distinctive combos. As seen in Table 4b, Kodoo offered a particular $35 \$$ plan that includes unlimited Canadian local and long distance on evenings and weekends starting at $7 \mathrm{pm}$ (or at $5 \mathrm{pm}$ for an additional \$5), with 300 minutes of local airtime, 50 local and international text messages. Kodoo proposed enhancements to the latter plan for $45 \$$. In other words, for an extra $10 \$$, the messages would now be unlimited and the costumer could use his unlimited Canadian long distance calls at all times. This shows an effort by Kodoo to attract a clientele that would care for Canadian long distance calling options. As for Fido, it seemed to target a different type of clients by bringing the "Full Fido" packages. It indeed, offered two new bundles, one for $\$ 40$ with 2,000 minutes within the urban area along with unlimited text messaging; and a $\$ 60$ bundle with 4,000 minutes in the urban area and an unlimited text messaging option. This effort to differentiate their products and search for a niche market can be seen as an endeavour to differentiate their products to counter the close competition in the packages presented in Tables 2 and 3. 
$\underline{\text { Table } 4 \mathrm{a}}$

\begin{tabular}{|l|c|c|}
\hline \multicolumn{2}{|l|}{ Fido (Nov 08) } \\
\hline $\begin{array}{l}\text { Announced } \\
\text { package price }\end{array}$ & $\$ 40$ & $\$ 60$ \\
\hline Activation Fee & $\begin{array}{c}\$ 25 \text { or } \\
\$ 35\end{array}$ & $\begin{array}{c}\$ 25 \text { or } \\
\$ 35\end{array}$ \\
\hline $\begin{array}{l}\text { Anytime } \\
\text { Minutes }\end{array}$ & 2,000 & 4,000 \\
\hline Text Messages & Unlimited & Unlimited \\
\hline
\end{tabular}

**this option is valid for local and international text and picture messaging $\underline{\text { Table } 4 \mathrm{~b}}$

\begin{tabular}{|l|c|c|}
\hline \multicolumn{3}{|l|}{ Kodoo (Nov 08) } \\
\hline $\begin{array}{l}\text { Announced } \\
\text { package price }\end{array}$ & $\$ 35$ & $\$ 45$ \\
\hline Anytime Minutes & 300 & 300 \\
\hline $\begin{array}{l}\text { Text Messages } \\
\text { Distance within } \\
\text { Canada }\end{array}$ & Week-ends & At all times \\
\hline $\begin{array}{l}\text { Unlimited } \\
\text { Evenings and } \\
\text { Week-ends at 7pm } \\
\text { (or at 5pm for an } \\
\text { extra \$5) }\end{array}$ & $\checkmark$ & Unlimited** \\
\hline $\begin{array}{l}\text { Call Waiting } \\
\text { Conference Call }\end{array}$ & $\checkmark$ & $\checkmark$ \\
\hline
\end{tabular}

Some discrepancies in the add-on options have emerged from the comparison of both November brochures. Kodoo's Call display option is offered at $1 \$$ less than Fido. As for the Voice Mail option, Kodoo also offers the service for $1 \$$ less than Fido, however it only holds 10 messages contrary to Fido who allows for 50 voice messages. As for the Call Forwarding option, even though it is priced similarly by both companies, Fido only allows for 2500 minutes whereas Kodoo's offer is unlimited. 


\section{Table 5}

\begin{tabular}{|l|c|c|}
\hline Package & Fido (Nov 08) & Kodoo (Nov 08) \\
\hline Call Display & $\begin{array}{c}\$ 6 \\
\text { (with Name Display) }\end{array}$ & $\$ 5$ \\
\hline Voice Mail & $\begin{array}{c}\$ 6 \\
\text { (holds 50 messages) }\end{array}$ & $\begin{array}{c}\$ 5 \\
\text { (holds 10 messages) }\end{array}$ \\
\hline Call Forwarding & $\$ 3$ & $\$ 3$ \\
& $(2500$ minutes) & (Unlimited) \\
\hline
\end{tabular}

The previous options showed in general lower pricing provided by Koodo, but this doesn't cover all of the options' list. In fact, some similar options were offered at the same price. For instance, both companies charged $\$ 10 /$ month for the unlimited incoming calls option, no difference is noted either in the $5 \mathrm{pm}$ early evenings option that is charged at $\$ 10 /$ month. The same thing goes for the unlimited on-device mobile browsing option that is offered at $\$ 7 /$ month, for unlimited Canadian long distance option at \$20/ month and for the unlimited North American long distance option at \$30/month.

So far, we have reached a stage in our analytical comparison where we found that a potential client would be generally better off with Koodo. This would be found if he was to solely rely on prices, packages, and add-on options regardless of any other factors that might affect his decision. In effect, Koodo will allow him to pay less for probably more services. However, this is true keeping in mind that these assumptions are also disregarding the quality of the service and the customer service satisfaction. Those were indeed not incorporated in the decision of this potential client. It is therefore to be noted that Fido charged a fixed activation fee but would offer a free notification message to its clients who have reached $70 \%$ and $100 \%$ of their talking limit, a service that wasn't given to any of Koodo's clients. 
Having detected signs of price competition in phase 2 of game 1, this could help supporting the assumption that competition is made amongst strategic substitutes. Therefore, the incumbent's first period strategy when faced with accommodation of entry could be assumed to take the form of a Puppy Dog. If we recall Fudenberg and Tirole's table, this situation is characterized by $R^{\prime}>0$ and $\frac{\partial \Pi_{F}}{\partial x_{F}}<0$ under accommodation of entry. It is to be noted that in this specific industry and during the timeframe considered, firms try to adopt the best market strategy they can find with the market information available to them. This is however a potentially complex market decision since each established company seeks to compete against fellow incumbents while strategically positioning itself to face the imminent threat of entry. Thus, making phase 2 of game 1 concurrent with phase 1 of game 2. This finding adds to the complexity of the analysis while also making it more interesting to examine.

Undeniably, this simultaneity in phases triggers new interests in the examination of the following data. Consequently, we would no longer only focus at uncovering whether the type of competition was in prices or quantities, but we would also need to expose the type of strategy that the market adopted when faced with the upcoming entry of new licence holders.

Interestingly, the market seemed to have reached a relatively stable status where Fido, Solo, Virgin and Koodo seem to have adopted similar market strategies by providing relatively homogeneous goods with slight differentiation that mostly made Koodo more affordable. Accordingly, the next round of brochure launching coincided for both leading companies in the beginning of 2009.

The second round of packages was first initiated by Koodo in January 2009 and followed by Fido in February 2009. As we will see, a large part of Koodo's bundles would have been preferred over Fido's offers. Koodo's basic products included persecond billing, conference call and call waiting and no activation fee. As seen in Table 6 , the $20 \$$ and $25 \$$ packages didn't change and still gave a slight edge to Kodoo. As for the 15 plan, the only change was noticed with Kodoo's plan that added the option of sending international text messages. 
$\underline{\text { Table } 6}$

\begin{tabular}{|c|c|c|c|c|c|c|}
\hline & $\begin{array}{c}\text { Fido } \\
\text { (Feb 09) }\end{array}$ & $\begin{array}{l}\text { Kodoo } \\
\text { (Jan 09) }\end{array}$ & $\begin{array}{c}\text { Fido } \\
\text { (Feb 09) }\end{array}$ & $\begin{array}{l}\text { Kodoo } \\
\text { (Jan 09) }\end{array}$ & $\begin{array}{c}\text { Fido } \\
\text { (Feb 09) }\end{array}$ & $\begin{array}{l}\text { Kodoo } \\
\text { (Jan 09) }\end{array}$ \\
\hline $\begin{array}{l}\text { Announced } \\
\text { package price }\end{array}$ & \multicolumn{2}{|c|}{$\$ 15$} & \multicolumn{2}{|c|}{$\$ 20$} & \multicolumn{2}{|c|}{$\$ 25$} \\
\hline Activation Fee & $\begin{array}{c}\$ 25 \text { or } \\
\$ 35\end{array}$ & $x$ & $\begin{array}{c}\$ 25 \text { or } \\
\$ 35\end{array}$ & $x$ & $\begin{array}{c}\$ 25 \text { or } \\
\$ 35\end{array}$ & $x$ \\
\hline $\begin{array}{l}\text { Anytime } \\
\text { Minutes }\end{array}$ & 50 & 50 & 50 & 100 & 100 & 100 \\
\hline $\begin{array}{l}\text { Text Messages } \\
\text { (local) }\end{array}$ & 50 & $50 *$ & 50 & $50 *$ & Unlimited & Unlimited $* *$ \\
\hline $\begin{array}{l}\text { Unlimited } \\
\text { Evenings and } \\
\text { Week-ends at } \\
7 \mathrm{pm}\end{array}$ & $x$ & $x$ & $\checkmark$ & $\checkmark$ & $\checkmark$ & $\checkmark$ \\
\hline Call Waiting & $\checkmark$ & $\checkmark$ & $\checkmark$ & $\checkmark$ & $\checkmark$ & $\checkmark$ \\
\hline Conference Call & $\checkmark$ & $\checkmark$ & $\checkmark$ & $\checkmark$ & $\checkmark$ & $\checkmark$ \\
\hline
\end{tabular}

When taking a closer look at other pricing plans, there seem to be some loose competition amongst providers which allowed for a light product differentiation. This made choosing between Fido and Koodo difficult if we were to solely rely on the aforementioned decision criterion. As seen in Table 7, Fido's $35 \$$ plan offered 50 more talking minutes than Kodoo, whereas Kodoo, gave local and international text and picture messaging and started its evenings at $5 \mathrm{pm}$ pm instead of $7 \mathrm{pm}$.

Most importantly, when comparing Fido’s 50\$ plan with Kodoo’s 45\$ plan, one might notice that Kodoo is giving more minutes and less texts, while Fido is giving unlimited texting. The same is noticed when comparing Fido's $70 \$$ and Kodoo's $65 \$$ bundle. If we take a closer look at Kodoo's add-on options, we would notice that with an additional $5 \$$ to allow for unlimited texting, Kodoo's costumers would now pay $50 \$$ 
$(45 \$+5 \$)$ or $70 \$(65 \$+5 \$)$ and receive more services than Fido would have offered them for the same amount.

Table 7

\begin{tabular}{|c|c|c|c|c|c|c|c|}
\hline & $\begin{array}{c}\text { Fido } \\
\text { (Feb 09) }\end{array}$ & $\begin{array}{l}\text { Kodoo } \\
\text { (Jan 09) }\end{array}$ & $\begin{array}{l}\text { Kodoo } \\
\text { (Jan 09) }\end{array}$ & $\begin{array}{c}\text { Fido } \\
\text { (Feb 09) }\end{array}$ & $\begin{array}{l}\text { Kodoo } \\
\text { (Jan 09) }\end{array}$ & $\begin{array}{c}\text { Fido } \\
\text { (Feb 09) }\end{array}$ & $\begin{array}{l}\text { Kodoo } \\
\text { (Jan 09) }\end{array}$ \\
\hline $\begin{array}{l}\text { Announced } \\
\text { package } \\
\text { price }\end{array}$ & $\$ 35$ & $\$ 35$ & $\$ 30$ & $\$ 50$ & $\$ 45$ & $\$ 70$ & $\$ 65$ \\
\hline $\begin{array}{l}\text { Activation } \\
\text { Fee }\end{array}$ & $\begin{array}{c}\$ 25 \text { or } \\
\$ 35\end{array}$ & $x$ & $x$ & $\begin{array}{c}\$ 25 \text { or } \\
\$ 35\end{array}$ & $x$ & $\begin{array}{c}\$ 25 \text { or } \\
\$ 35\end{array}$ & $x$ \\
\hline $\begin{array}{l}\text { Anytime } \\
\text { Minutes }\end{array}$ & 350 & 300 & 300 & 600 & 750 & 2000 & 2000 \\
\hline $\begin{array}{l}\text { Text } \\
\text { Messages } \\
\text { (local) }\end{array}$ & Unlimited & Unlimited $* *$ & $50 *$ & Unlimited & $50 *$ & Unlimited & $50 *$ \\
\hline $\begin{array}{l}\text { Unlimited } \\
\text { Evenings } \\
\text { and Week- } \\
\text { ends }\end{array}$ & $7 \mathrm{pm}$ & $5 \mathrm{pm}$ & $7 \mathrm{pm}$ & $7 \mathrm{pm}$ & $7 \mathrm{pm}$ & $7 \mathrm{pm}$ & $7 \mathrm{pm}$ \\
\hline $\begin{array}{l}\text { Call } \\
\text { Waiting }\end{array}$ & $\checkmark$ & $\checkmark$ & $\checkmark$ & $\checkmark$ & $\checkmark$ & $\checkmark$ & $\checkmark$ \\
\hline $\begin{array}{l}\text { Conference } \\
\text { Call }\end{array}$ & $\checkmark$ & $\checkmark$ & $\checkmark$ & $\checkmark$ & $\checkmark$ & $\checkmark$ & $\checkmark$ \\
\hline
\end{tabular}

*this option is valid for local and international text messaging

**this option is valid for local and international text and picture messaging

The freedom given to Koodo's customers to pay $\$ 45$ and get 50 messages or pay $\$ 5$ more and get unlimited local and international text and picture messaging, allows Koodo to attract customers with very specific preferences. Fido, doesn't seem to be working as hard to provide these flexibilities that could better serve the preferences of its clients. The same flexibility is observed in Koodo's \$65 combo and Fido's \$70 one. 
This semester, Koodo offered a different package for $\$ 45$ and $\$ 50$ that once again combined different services in an apparent search for a niche market that targets clients with needs for long distance correspondence.

As for Fido, its Full Fido allowed once more for a relatively high offer of minutes for an urban living clientele.

Table 8

\begin{tabular}{|l|c|c|}
\hline \multicolumn{2}{|l|}{ Fido (Feb 09) } \\
\hline $\begin{array}{l}\text { Announced } \\
\text { package price }\end{array}$ & $\$ 40$ & $\$ 60$ \\
\hline Activation Fee & $\begin{array}{c}\$ 25 \text { or } \\
\$ 35\end{array}$ & $\begin{array}{c}\$ 25 \text { or } \\
\$ 35\end{array}$ \\
\hline $\begin{array}{l}\text { Anytime } \\
\text { Minutes }\end{array}$ & 2,000 & 4,000 \\
\hline Text Messages & Unlimited & Unlimited \\
\hline
\end{tabular}

\begin{tabular}{|l|c|c|}
\hline \multicolumn{2}{|l|}{ Kodoo (Jan09) } \\
\hline Announced package price & $\$ 45$ & $\$ 50$ \\
\hline Anytime Minutes & $300^{* * *}$ & 750 \\
\hline Text Messages & Unlimited** & $50^{*}$ \\
\hline $\begin{array}{l}\text { Unlimited Evenings and } \\
\text { Week Ends (local calls) }\end{array}$ & $7 \mathrm{pm}$ & $5 \mathrm{pm}$ \\
\hline $\begin{array}{l}\text { Unlimited Evenings and } \\
\text { Week-ends at 5pm to local } \\
\text { and Canadian long distance } \\
\text { calls }\end{array}$ & $\mathbf{}$ & $\checkmark$ \\
\hline Call Waiting & $\checkmark$ & $\checkmark$ \\
\hline Conference Call & $\checkmark$ & $\checkmark$ \\
\hline
\end{tabular}

*this option is valid for local and international text messaging

**this option is valid for local and international text and picture messaging

$* * *$ this option allows for nationwide phone conversations

This is the clearest product differentiation so far, where Fido is aiming at attracting clients who are essentially interested in talking with local urban people, whereas Koodo is aiming at attracting clients who might be interested in communicating with by voice calls to other Canadian provinces and by messaging to people all over the world. Fido's approach to target interconnected urban living clients reminds us of Fido's early market strategies with the "City Fido". As for Kodoo, it seems to seek 
popularity amongst newcomers could they be Canadians from other provinces or immigrants. Kodoo's effort to maintain the option for international texts and pictures can be very attractive to immigrants who wish to connect with friends and family back home. Kodoo's international messaging option can be the reason for newcomers to Canada to go with Kodoo instead of Fido. Kodoo needs to make this extra effort since it operates on a CDMA technology that is only operational in North America. Fido who operates on a GSM network can be more attractive to foreigners since the technology is used in the rest of the world. This allows for GSM customers to keep their phone when travelling, which cannot be done with CDMA users.

As seen previously, Koodo did trigger a drop in prices in the discount market, but it is difficult to assess at this point if prices became closer to covering the fixed costs of the operating firms (thus leading to a money-losing Bertrand ${ }^{13}$ equilibrium). It is not also clear if profit per customer dropped, and if it did, by how much for each bundle?

For instance, among the "old" Fido plans such as the one offered in August 2008 (ref Table 9), there was a $\$ 30$ bundle that effectively costs $\$ 37.45$. It provided, without a contract, 100 minutes of local Airtime and 50 extra minutes with a 3-years-contract, $7 \mathrm{pm}$ unlimited nights and weekends, and unlimited incoming calls. If we take a closer look at the $\$ 25$ bundle offered by the "new" Fido in June 2009, it offers 100 minutes of local airtime and $7 \mathrm{pm}$ night and weekends with unlimited text messaging.

If a potential customer would be interested in having unlimited incoming calls in his "new Fido" package, it will cost $\$ 10$ on top of the initial $\$ 25$ bundle. So this potential customer would receive for \$35: 100 minutes of local talk time, 7pm evenings and weekends, unlimited text messaging and unlimited incoming calls.

\footnotetext{
${ }^{13}$ This equilibrium is reached in a competition amongst "non-differentiated goods". This particularity makes consumers only interested in the lowest priced good when they will want to decide which product to buy. Therefore, when two firms are competing in this type of market, the firm that gives the lowest price will attract the entire demand for that good. This will lead to a price war between the two companies that will push their prices to the level of their marginal cost, thus generating no losses for both companies.
} 
This package is $\$ 2.45$ cheaper than the old $\$ 37.45$ Fido package. It provides unlimited texting option (the old Fido package doesn't), but gives 50 less talk time than the old committed Fido bundle. So if we consider that the client would have gotten a longterm contract regardless of the timing of his choice (old Fido or new Fido), then apart from the $\$ 2.45$ difference in price, the old one would provide 50 extra talk time and the new one would allow for unlimited text messaging.

$\underline{\text { Table } 9}$

\begin{tabular}{|c|c|c|}
\hline Package & $\begin{array}{l}\text { "old" Fido } \\
\text { (August 08) }\end{array}$ & $\begin{array}{l}\text { "new" Fido } \\
\text { (June 09) }\end{array}$ \\
\hline Announced package price & $\$ 30$ & $\$ 25$ \\
\hline $\begin{array}{l}\text { Effective package price } \\
\text { (with system access fee } \\
\text { and } 911 \text { fees) }\end{array}$ & $\$ 37.45$ & $\$ 25$ \\
\hline Activation Fee & $\$ 15$ & $\$ 25$ or $\$ 35$ \\
\hline Anytime Minutes & $\begin{array}{c}100 \\
(+50 \text { with a } 3 \text { years } \\
\text { contract })\end{array}$ & 100 \\
\hline Text Messages & $x$ & Unlimited \\
\hline Incoming calls & Unlimited & $x$ \\
\hline $\begin{array}{l}\text { Unlimited Evenings and } \\
\text { Week-ends at } 7 \mathrm{pm}\end{array}$ & $\checkmark$ & $\checkmark$ \\
\hline Call Waiting & $\checkmark$ & $\checkmark$ \\
\hline Conference Call & $\checkmark$ & $\checkmark$ \\
\hline
\end{tabular}

Considering that providing texting options is much less costly to provide than calling services, it would be interesting to get access to data that would clarify by how much less does a text cost to provide compared to a phone call (in terms of opportunity cost of crowding less bandwidths). Another important factor to be considered is the average number of text messages used by customers with the unlimited texting option. Both sets of information would allow us to shed light on whether 50 minutes of talk time 
will cost the same as providing unlimited texting with a $\$ 2.45$ difference per client. This would then clarify how the profit per client varied with this change of image and market strategy.

It is to be noted that this is only applicable for the old $37.45 \$$ bundle and the new $25 \$$ bundle (with $\$ 10$ for the unlimited incoming calls), and is in no way able to confirm that the same scenario is repeated for the remaining bundles which are tougher to compare. Indeed, since the drop in prices, and the offering of a different range of products, bundles are fashioned in a different way which adds to the complexity of price comparison (that cannot be solved with the data available).

In phase-one, incumbents offered for a higher price more talking options and merely any texting options. But in phase-two, the trend was moving toward less talk time and more texting options with no bundle including unlimited incoming calls and no extra options granted in exchange of a long-term commitment.

Whatever may be the profit per client triggered by Koodo's entry, it is imminent to examine the market changes and interactions in phase-two. Koodo, Fido, Solo and Virgin were now mainly competing in prices for very similar products. But have market prices hit the marginal cost level?

\subsection{Intuition for Game 2 - Phase 2}

It is therefore relatively safe to state that Fido and Koodo are competing in prices in most of their products. It is to be noted however that Koodo might have found a niche market that allows it to be more attractive to a portion of the market, when Fido also worked on settling its own strictly local/urban clientele.

It has been considered until now that Koodo has an edge in its pricing plans for the targeted clientele that it is competing for with Fido. This might be seen as a price war if Koodo and Fido's prices are getting close to the level of their marinal costs. If it was 
so, a Bertrand equilibrium would be expected to be reached soon. But since we do not have sufficient information over the cost of operation or the fixed costs incurred by both companies, then this interaction could be seen as part of a regular price competition.

It is however crucial to acknowledge that the present incumbents (i.e. Fido, Koodo, Solo and Virgin) are under a high alert of upcoming disturbances. Indeed, the market is aware and preparing itself to welcome new players in the game. Those forthcoming new players are no other than the winners of the summer 2008 auction, who are preparing themselves and investing to enter the market soon.

Consequently, competitive actions in the current discount market could also be considered as reactions to this upcoming new threat. In other words, the recent interactions that followed Koodo's entry and that were mainly revolving around price competition, might at the same time explain the market's pre-emptive strategy to deter or limit the entry size of those new players.

Thus if incumbents (i.e. Fido, Koodo, Solo and Virgin) are competing in prices in the now first-period of game2, they might be doing so to accumulate a relatively significant customer base. In addition to that, Telus and Bell are both investing in their infrastructure in order to acquire the "third generation" or "3G" technology (which is already operational in Rogers). This might lead us to think that they are intending to look "tough" in the eyes of the auction winners.

Contrary to phase 1 of game 1 , the incumbents in phase 1 of game 2 seem more aggressively preparing to face the threat of entry. If we borrow once again Burger and Kolstad's findings, the market seem to jointly invest in that "public good" in order to deter or accommodate entry. In phase 1 of game 1, high levels of uncertainty were linked to Koodo's time of entry as well as its hopeful success. Moreover, since Koodo was to be launched by Telus (an already established provider), the benefits from deterring the entry of that new discount brand didn't seem too interesting to incumbents when compared to the costs it will entail. However, in the new dynamics 
of the market that occurred in phase 1 of game 2 , uncertainly over the entry timing of new licence holders is weak. Indeed, many expect that these new providers will launch their products at the beginning of 2010. Also, having to face several new actors in the industry, incumbents might view higher benefits in adopting an aggressive strategy to fight the entrants.

In consequence, the incumbent firms seem to be accumulating clients, and committing them to their services via long-term contracts, or by integrating them to their interdependent network of clients (through their "Fido to Fido" and "Koodo to Koodo" option). Concurrently with that, a part of these incumbents are also investing in their infrastructure. One is lead to go back to Fudenberg and Tirole(1984) and Bulow, Geanakoplos and Klemperer (1985) to try to understand what might be happening in phase 2 of game 2 .

There will be two situations to consider. First, the case of a deterred entry, and second the case of an accommodation of entry. Since there is not solid proof that all license holders will enter the market, it would be safe for now to consider all possibilities.

Firstly, let us consider the entry deterrence case where the following relation will direct the decision of firm 1 :

$$
\frac{d \Pi^{2}}{d K_{1}}=\frac{\partial \Pi^{2}}{\underbrace{\partial K_{1}}_{\begin{array}{c}
\text { Direct } \\
\text { effect }
\end{array}}}+\underbrace{\frac{\partial \Pi^{2}}{\partial x_{1}} \frac{d x_{1}^{*}}{d K_{1}}}_{\begin{array}{c}
\text { Strategic } \\
\text { effect }
\end{array}}
$$

We have reasons to believe that the sign of the strategic effect in this situation is negative since in the Canadian wireless discount market, it has been considered that the type of capital that is currently invested makes firms look "tough". Therefore, we find $\frac{d \Pi_{2}}{d K_{1}}<0$. The sign of the direct effect could be negative or null, since there is both types of investment occurring (in the technology and in accumulating clients), however the exact sign needn't be determined. In effect, having a negative sign from the strategic effect, and a null or negative sign from the direct effect, then we will have 
$\frac{d \Pi^{2}}{d K_{1}}<0$ in both cases. Accordingly, in order to deter entry, firm 1 would "overinvest" to look tough. In other words, it should follow the "Top Dog" Strategy if we refer to Fudenberg and Tirole's animal terminology. It is to be assumed with the information available to us that the "Top Dog" strategy could be used by incumbents whether second-period competition will be in prices or in quantities.

Secondly, let's consider the case of an accommodation of entry, where the following relation will affect firm 1's behaviour:

$$
\operatorname{sign}\left(\frac{\partial \Pi_{F}}{\partial x_{K}} \frac{d x_{F}^{*}}{d K_{F}}\right)=\operatorname{sign}\left(\frac{\partial \Pi_{K}}{\partial x_{F}} \frac{d x_{F}^{*}}{d K_{F}}\right) \times \operatorname{sign}\left(R_{K}^{\prime}\right)
$$

Since this model considers that investment makes the incumbent look "tough", then the following relation will affect the sign of the strategic effect, and thus $\frac{d \Pi_{2}}{d K_{1}}<0$.

On the one hand, if the second-period competition will be in prices, then $R_{K}^{\prime}>0$. The model predicts that in the presence of the decision to accommodate entry, the first period will be characterized by a "Puppy Dog" strategy adopted by firm 1 . Therefore firm1 will "underinvest" in order to induce a softer behaviour from its upcoming competition.

On the other hand, if the second period competition is in quantities, then $R_{K}^{\prime}<0$. The model predicts this time, that in the presence of a decision to accommodate entry, the first period behaviour will be characterized by a "Top Dog" strategy adopted by firm 1. Therefore it shows that whether firm 1 chooses to deter or accommodate entry, if the second period competition will be in quantities, then the "Top Dog" strategy will be followed. This will be done by investing to look tough, in order to induce a softer behaviour from the new entrants. 


\section{IV- Discussion and concluding remarks:}

The model assumes either a quantity or price competition in phase 2 of each game, but the truth is that in such complex markets, there will be a combination of both. Which one will prevail? This is a question that needs to be further investigated. It has been shown in phase 2 of game 1, that firms were competing in prices, while accumulating various forms of capital with commitment value (signing long-term contract with their clients, providing phones with CDMA technology that is difficult to use with a different provider, building an interdependent network of clients, modernising their infrastructure, etc.). This period which also happens to be the phase 1 of game 2 , is characterized by strategic actions undertaken to affect the entry size and/or decision of the potential new entrants. Since the current market is still in that first stage of game 2 , there isn't yet a clear image of the type of competition that will be carried out during phase 2 . Hence, the need to uncover if the market has the ability to deter the entry of some potential providers or if accommodation will be the incumbents' only option.

On the one hand, Videotron's timid start in the wireless service, has gained great respect given that they were able to steal 1 million customers from Bell in the past two years ${ }^{14}$. In addition to that, Videotron is the only new provider that acquired licences for operating in the Province of Quebec. Indeed, in the 2008 spectrum auction, Quebecor aggressively bought all the licences offered for Quebec's wireless market, thus making them the only new entrant in the Quebec market ${ }^{15}$. On the other hand, Globalive who was supposed to launch its new brand "Wind" earlier in 2009, faced some legal difficulties. In fact, the $\mathrm{CRTC}^{16}$ accused Globalive of being operated by a non-Canadian company which causes conflict with legal requirements ${ }^{17}$. Globalive is indeed partly owned by Orascom, an Egyptian company, however, the Industry

\footnotetext{
${ }^{14}$ Mercure, P. "Rogers maintient le cap", La Presse Affaires, 11-19-09.

${ }^{15}$ Lasalle, L. "Canada trying to open up cellphone industry with spectrum auction". Canadian Press. 3-07-08.

${ }^{16}$ Canadian Radio and Television Telecommunications Commission

${ }^{17}$ Lasalle, L. "Globalive to take on Rogers, Bell and Telus using smartphones as a weapon". Canadian Press. 12-13-09.
} 
Minister Tony Clement eventually allowed for Wind to launch its products after confirming that Globalive is indeed a Canadian-owned and operated company. Globalive aims to be the new provider that will rival the big three, an ambitious project that could bring new dynamics to the market. In sum, these two providers, Videotron and Golbalive, are the ones that are expected to trigger the most changes in the market, therefore their actions should be watched closely in the following stages of this game.

Moreover, the new type of market competition triggered by Koodo's entry, revealed an apparent drop in prices. However, further investigation of these prices, showed that "discount" companies, did drop their prices, but offered less services at lower costs. This might lead to think that profit per client may not have been affected. Therefore, this questions the transparency of information in this market - especially since the current discount providers' advertising campaigns are portraying a new era of low prices for 'great' services. There is also a need to investigate how these providers are perceived by their potential and present clients. Indeed, are the latter aware that the advertised lower prices are not necessarily synonym with cheaper bundles if they are looking for the same type of services that were previously found in the market before Koodo's entry? In addition to that, how much are they aware of the upcoming market changes that might result in lower prices, and how did it affect their present decisions: did it encourage them to wait and observe the market, or did it push them to negotiate better services with the current providers?

Even though this research limits its analysis to the "Discount" market, it is still giving an interesting picture of the continuous interactions in the wireless industry. It is however vital to point out that there is a dichotomy in the mother companies' market strategies when compared to their discount brands' strategies. In effect, Telus, Rogers and Bell are holding on to their high prices and their system access fees. It is their way to attract a different type of clientele that is willing to pay more for more efficient and more sophisticated services. Telus was an apparent victim of its daughter company's success, as Koodo might have unwillingly attracted clients that were potentially 
considered in Telus' targeted market. However, this loss from "cannibalisation" might have been overcompensated by the gains of attracting all of Koodo's clients. This strategy seems to have been efficient after all since Virgin publicly declared a war to Rogers by accusing it of exchanging its system access fees with higher priced services ${ }^{18}$. This scenario is similar to Koodo's advertising campaigns, particularly since Virgin is also a daughter company of a big three. This might boost Virgin's popularity at the cost of Bell's. But can Koodo's success be replicated? This remains to be proven.

\footnotetext{
${ }^{18}$ Bergeron, M. "Nouvelle guéguerre Virgin-Rogers”, La Presse Affaires, 11-11-09.
} 


\section{V- References}

Baldini, J. (1983), "Strategic advertising and credible entry deterrence policies", Mimeo.

Baum, J. And Korn, H. (1999). “ Dynamics of dyadic competitive interaction”, Strategic Management Journal, 20: 251-278.

BCE, press release, "Bell Canada lance un nouveau service sans fil destiné aux jeunes", 0725-05. http://www.bce.ca/fr/news/releases/bm/2005/07/25/72567.html

Bergeron, M. “ Nouvelle guéguerre Virgin-Rogers”, La Presse Affaires, 11-11-09.

Bernheim, D. (1984). "Strategic Entry deterrence of sequential entry into an industry", Rand Journal of Economics, 15, 1-11.

Bérubé, G. “Telus lance sa téléphonie à escompte”, Le Devoir, 04-01-08.

Boston Consulting Group. (1972). Perspectives on Experience.

Boyer, M. (2005). "The measure and regulation of competition in telecommunications markets", CIRANO, 2005s -35.

Boyer, M., Gravel, E., and Lasserre, P. (2008). "Real Options and strategic competition: A survery". Mimeo CIRANO.

Boyer, M., Mahenc, P. And Moreaux, M. (2003). "Entry preventiong locations under incomplete information”, International Journal of Industrial Organization, 21: 809-829.

Boyer, M. and Moreaux, M. (1997). "Capacity commitment versus flexibility”, Journal of Economics and Management Strategy, 6/2: 347-376.

Boyer, M. and Moreaux, M. (1999). "Strategic underinvestment in informative advertising: The cases of substitutes and complements", The Canadian Journal of Economics, 32/3: 654672.

Bulow, J., Geanakoplos, J. and Klemperer, P. (1985). "Multimarket oligopoly: Strategic substitutes and complements", Journal of Political Economy, 93:488-511.

Burger, N. and Kolstad, C. (2009). "Voluntary public goods provision, coalition formation, and uncertainty", National Bureau of Economic Research, Working Paper 15543.

Caves, R. and Porter, M. (1977). "From entry barriers to mobility barriers", Quarterly Journal of Economics, 9: 241-267.

Edwards, C. (1979). "The multimarket enterprise and economic power: Remarks upon receipt of the Veblen-Commons Award”, Journal of Economic Issues, 13: 285-301. 
Fudenberg, D., and Tirole, J. (1984). "The fact cat effect, the Puppy Dog Ploy and the Lean and Hungry Look", American Economic Review, Papers and Proceedings , 74: 361-368.

Fudenberg, D. and Tirole, J. (1991). Game Theory, The MIT Press, Cambridge Massachusetts and London, England.

Gilbert, R., and Vives, X. (1986). "Entry deterrence and the free rider problem", Review of Economic Studies, 53: 71-83.

Lasalle, L. "Canada trying to open up cellphone industry with spectrum auction". Canadian Press. 3-07-08.

Lasalle, L. "Globalive to take on Rogers, Bell and Telus using smartphones as a weapon". Canadian Press. 12-13-09.

Mascarenhas, B. And Aaker, D. (1989). "Mobility barriers and strategic groups", Strategic Management Journal, 10: 475-485.

Mercure, P. "Rogers maintient le cap”, La Presse Affaires, 11-19-09.

Salop, S. and Scheffman, D. (1983). "Raising rivals' costs", American Economic Review, Papers and Proceedings, 28: 476-493.

Samuelson, P. (1954). "The pure theory of public expenditure", The Review of Economics and Statistics, 36/4: 387-389.

Schmalensee, R. (1983). "Advertising and entry deterrence: an exploratory model”, Journal of Political Economy, 90: 636-653.

Sturgeon, J. "Bell Canada acquires 100\% of Virgin Mobile Canada", National Post, 05-0709.

Swift, A. "Rogers prend les commandes de Fido", Le Devoir , 11-09-04.

Tirole, J. (1988). Theory of Industrial Organization. The MIT Press, Cambridge Massachusetts and London, England.

Tombak, M. (2005)."Strategic Asymmetry", Journal of Economic Behavior and Organization, 61: 339-350.

Waldman, M. (1987). "Non- cooperative entry deterrence, uncertainty and the free rider problem”, Review of Economics studies, 54: 301-310. 